\title{
PENGARUH PERBANDINGAN MOCAF (Modified Cassava Flour) DENGAN TEPUNG KACANG HIJAU (Vigna radiata) TERHADAP KARAKTERISTIK TUILE
}

\author{
The Effects of Mocaf (Modified Cassava Flour) and Mung Bean Flour (Vigna Radiata) Ratio on the \\ Characteristic of Tuile
}

\author{
I Made Dwi Purnama Rianta ${ }^{1)}$, Putu Timur Ina ${ }^{2)}$, I Wayan Rai Widarta ${ }^{2)}$ \\ ${ }^{1}$ Mahasiswa Program Studi Ilmu dan Teknologi Pangan, Fakultas Teknologi Pertanian, Universitas Udayana \\ ${ }^{2}$ Dosen Program Studi Ilmu dan Teknologi Pangan, Fakultas Teknologi Pertanian, Universitas Udayana \\ Kampus Bukit Jimbaran, Badung-Bali
}

\begin{abstract}
This research was conducted with the aims to determine the effect of mocaf and mung bean flour to the characteristics of tuile and get a certain ratio of mocaf and mung bean flour which able to produce tuile with the best characteristics. This research used randomized block design with treatment factor is the ratio of mocaf and mung bean flour which consist of 6 levels: 100\%:0\%; 90\%:10\%; 80\%:20\%; 70\%:30\%; 60\%:40\%; and 50\%:50\%. The treatment was repeated 3 times to obtain 18 units of experiment. The data were analyzed with Analysis of Variance method and if the treatment had an effect on the variable, the Duncan test were performed. The results showed that the ratio of mocaf and mung bean flour had an effect on water content, ash content, protein content, crude fiber content, carbohydrate content, color, taste (hedonic test), texture (hedonic test and scoring test) and overall acceptance (hedonic test). Ratio of 70\% mocaf : $30 \%$ mung bean flour is the best characteristic with 1,16\% water content, 1,46\% ash content, 8,54\% protein content, 15,49\% fat content, 73,33\% carbohydrate content, 5,36\% crude fiber content, rather liked color, rather liked flavor, crunchy and liked texture, rather liked taste, and overall acceptance is rather liked.
\end{abstract}

Keyword: mocaf, mung bean flour, tuile

\section{PENDAHULUAN}

Produk kue kering saat ini semakin beragam jenisnya. Salah satu jenis kue kering yang cukup diminati di Indonesia adalah tuile. Tuile dikembangkan di Surabaya yang biasanya dijadikan oleh-oleh. Variasi tuile di Indonesia telah berkembang dengan adanya penambahan topping dan rasa, seperti almond tuile, almond crispy cheese, almond crispy choco, dan almond crispy macha. Tuile merupakan kue kering asal Perancis yang dibuat dari campuran terigu, gula, putih telur dan margarin kemudian dibentuk bulat dan tipis sehingga menghasilkan tekstur yang renyah (Biró et al., 2005). Bahan utama dalam pembuatan tuile adalah terigu. Terigu saat ini masih menjadi masalah di Indonesia karena gandum sebagai bahan utama terigu tidak dapat ditanam di Indonesia. Hal tersebut yang

*Korespondesi Penulis :

E-mail: dwipurnamarianta@yahoo.com ${ }^{1)}$ menyebabkan terigu perlu diimpor ke Indonesia.

Indonesia memiliki sumber daya alam dan bahan pangan yang melimpah. Bahan pangan lokal sumber karbohidrat memiliki potensi yang mampu mengurangi konsumsi terigu di Indonesia. Singkong di Indonesia merupakan bahan pangan nomor tiga setelah padi dan jagung yaitu sebagai sumber karbohidrat serta penghasil kalori terbesar (Nusa et al., 2012). Produk intermediet singkong seperti mocaf (modified cassava flour) saat ini sudah dikembangkan untuk digunakan sebagai bahan pangan pengganti terigu. Mocaf (modified cassava flour) adalah tepung dari singkong yang dibuat dengan menggunakan prinsip modifikasi sel singkong secara fermentasi (Subagio, 2007a). 
Mocaf memiliki karakteristik pati yang mirip dengan terigu, sehingga dapat digunakan sebagai alternatif pengganti terigu sekaligus mendukung perkembangan produk pangan lokal. Keunggulan mocaf antara lain yaitu, mempunyai kandungan mineral lebih tinggi $(58 \mathrm{mg})$ dibanding padi $(6 \mathrm{mg})$, dan gandum (16 mg), mempunyai kandungan serat yang lebih tinggi $(3,4 \mathrm{mg})$ dibandingkan dengan terigu $(0,4 \mathrm{mg})$, mempunyai daya kembang yang setara dengan terigu, serta mempunyai daya cerna yang tinggi dibandingkan dengan tapioka (Subagio, 2008).

Pengembangan olahan tuile dengan bahan baku mocaf merupakan salah satu upaya yang dapat mengurangi konsumsi terigu di Indonesia. Tuile yang terbuat dari mocaf bebas dari kandungan gluten, sehingga dapat dikonsumsi oleh semua kalangan terutama penyandang celiac disease dan penyandang autism spectrum disorder (ASD) yang alergi terhadap gluten. Gluten adalah protein yang hanya terdapat di sebagian jenis serealia seperti gandum, oat, dan barley. Menurut Tanjung dan Kusnadi (2015), seorang yang mengalami alergi terhadap gluten akan menimbulkan perilaku hiperaktif ketika mengkonsumsi makanan yang mengandung gluten.

Menurut Subagio (2007a) kandungan protein pada mocaf masih terbilang kecil yaitu $1 \%$, sehingga perlu adanya penambahan bahan pangan lokal yang mengandung protein tinggi, salah satunya adalah kacang hijau. Kacang hijau merupakan salah satu sumber protein nabati. Kacang hijau memiliki kandungan protein yang cukup tinggi yaitu $22 \%$ dan merupakan sumber mineral yang penting antara lain kalsium dan fosfor. Kandungan lemak kacang hijau relatif sedikit yaitu $1-1,2 \%$ dan tersusun atas asam lemak tak jenuh. Kacang hijau juga mengandung serat sebanyak 4,1\% (Retnaningsih et al., 2008 dalam Nisa, 2016). Menurut Sidabutar et al. (2013), kacang hijau di Indonesia menempati urutan ketiga terpenting sebagai tanaman legum, setelah kedelai dan kacang tanah. Potensi tersebut dapat menjadikan kacang hijau sebagai sumber protein dalam suatu bahan pangan, dalam produksi tuile dengan bahan baku mocaf.

Tuile memiliki karakteristik yang menyerupai dengan biskuit. Tuile dengan karakteristik terbaik dapat dihasilkan, dengan menentukan perbandingan antara mocaf dan tepung kacang hijau yang tepat. Tanjung dan Kusnadi (2015), menyatakan bahwa biskuit yang terbuat dari perbandingan 55\% mocaf dan $45 \%$ tepung kacang hijau dengan penambahan $25 \%$ margarin menghasilkan karakteristik yang terbaik.

Sejauh ini, penelitian mengenai pembuatan tuile dari mocaf dengan penambahan tepung kacang hijau belum pernah dilakukan, sehingga perlu dilakukan penelitian mengenai karakteristik tuile yang terbuat dari mocaf dan tepung kacang hijau. Penggunaan mocaf dan tepung kacang hijau diharapkan dapat menghasilkan tuile yang bergizi dengan karaktersitik yang baik.

\section{METODE PENELITIAN}

\section{Tempat dan Waktu Penelitian}

Penelitian ini dilaksanakan di Laboratorium Analisis Pangan, Laboratorium Pengolahan Pangan, Laboratorium Biokimia dan Nutrisi, serta Laboratorium Rekayasa Proses dan Pengendalian Mutu Fakultas Teknologi Pertanian Universitas Udayana. Pelaksanaan penelitian ini dilakukan mulai bulan Juli sampai dengan bulan Agustus 2018.

\section{Bahan dan Alat}

Bahan-bahan yang digunakan dalam penelitian ini terdiri dari bahan utama, bahan pembantu dan bahan kimia. Bahan utama meliputi mocaf (Ladang Lima) dan tepung kacang hijau yang terbuat dari kacang hijau varietas lokal didapat dari supermarket Tiara Dewata, Denpasar. Bahan pembantu yang 
digunakan dalam pembuatan tuile meliputi gula halus, margarin (Blueband), dan telur yang didapat dari supermarket Tiara Dewata, Denpasar. Bahan kimia yang digunakan untuk analisis kimia antara lain tablet Kjeldahl, phenolphtalin, asam borat, $\mathrm{HCl}, \mathrm{NaOH}$, $\mathrm{H} 2 \mathrm{SO} 4$, aquades, asam sulfat, natrium hidroksida, asam sulfat, hexan, vaselin, dan alkohol.

Alat yang digunakan untuk membuat tuile adalah pisau, cetakan, waskom, panci, kukusan, blender (Phlips), timbangan digital (ACIS), oven (Blue M), dan sendok. Alat yang digunakan untuk analisis sifat fisik dan kimia adalah lumpang, desikator, cawan porselin, oven (Memmert), timbangan analitik (Shimadzu), pinset, muffle (Daihan), labu kjeldahl (Pyrex), labu erlenmeyer (Pyrex), gelas beaker (Pyrex), gelas ukur (Pyrex), destilator, biuret (Pyrex), pipet volume (Pyrex), pompa karet, labu takar (Pyrex), labu lemak (Pyrex), soxhlet, kertas whatman no 42 , kertas saring, corong, dan seperangkat alat untuk evaluasi sensoris.

\section{Rancangan Percobaan}

Rancangan yang digunakan pada penelitian ini adalah Rancangan Acak Kelompok (RAK) dengan faktor perlakuan perbandingan konsentrasi mocaf dan tepung kacang hijau yang digunakan pada pembuatan tuile yang terdiri dari 6 taraf yaitu: P1 (100\%:0\%), P2 (90\%:10\%), P3 (80\%:20\%), P4 (70\%:30\%), P5 (60\%:40\%), dan P6 (50\%:50\%). Masing-masing perlakuan diulang sebanyak 3 kali sehingga diperoleh 18 unit percobaan. Data yang diperoleh dianalisis dengan sidik ragam dan apabila perlakuan berpengaruh terhadap variabel yang diamati maka dilanjutkan dengan uji Duncan (Gomez dan Gomez, 1995).

\section{Pelaksanaan Penelitian}

Pelaksanaan penelitian untuk pembuatan tuile terdiri atas dua tahap yaitu:
Tahap I Pembuatan Tepung Kacang Hijau

Pembuatan tepung kacang hijau mengacu pada Ratnasari dan Yunita (2015) yang dimodifikasi. Kacang hijau dicuci bersih, kemudian dikukus selama 30 menit. Selanjutnya kacang hijau dikeringkan dengan menggunakan oven pada suhu $60^{\circ} \mathrm{C}$ selama 8 jam. Kacang hijau yang telah kering selanjutnya dihaluskan dengan menggunakan blender dan diayak dengan ayakan 60 mesh. Tepung kacang hijau yang dihasilkan dikemas di dalam plastik dalam keadaan tertutup hingga siap digunakan.

\section{Tahap II Pembuatan Tuile}

Pembuatan tuile mengacu pada (Anon., 2010) yang dimodifikasi. Pembuatan adonan tuile dilakukan dengan menggunakan teknik all-in method dimana mocaf : tepung kacang hijau (sesuai perlakuan), 40g gula halus dan 30g margarin, diaduk dengan menggunakan mixer selama 2 menit. Selanjutnya $60 \mathrm{~g}$ putih telur dimasukkan dan diaduk kembali selama 2 menit. Adonan yang telah homogen kemudian dibentuk dengan menggunakan cetakan plastik tipis berbentuk bulat dengan ketebalan $1 \mathrm{~mm}$ serta berdiameter lubang $8,5 \mathrm{~cm}$. Adonan dibentuk dengan teknik droping method yaitu adonan dituang pada lubang cetakan serta diratakan sesuai luas lubang dan ketebalan cetakan. Cetakan diangkat, selanjutnya adonan yang telah terbentuk dipanggang dengan menggunakan oven pada suhu $120^{\circ} \mathrm{C}$ selama 20 menit. Tuile yang telah matang didinginkan pada suhu ruang selama 5 menit agar tekstur tuile mengeras.

\section{Variabel yang Diamati}

Variabel yang diamati dalam penelitian ini adalah analisis kadar air dengan metode oven, kadar abu dengan metode kering, kadar protein dengan metode Mikro-Kjedhal, Kadar lemak dengan metode soxhlet, kadar serat kasar dilakukan dengan metode hidrolisis asam dan basa, kadar karbohidrat dilakukan dengan metode Carbohydrate by different 
(Sudarmadji et al., 1989) serta uji sensoris meliputi warna, aroma, rasa (uji hedonik), tekstur (uji hedonik dan uji skoring) dan penerimaan keseluruhan (uji hedonik) (Soekarto, 1985).

\section{HASIL DAN PEMBAHASAN}

Hasil analisis kadar air, kadar abu, kadar protein, kadar lemak, kadar karbohidrat dan kadar serat kasar dari mocaf dan tepung kacang hijau dapat dilihat pada Tabel 1.

\section{Hasil Analisis Kimia Dan Fisik}

Hasil analisis kadar air, kadar abu, kadar protein, kadar lemak, kadar karbohidrat dan kadar serat kasar dari tuile dapat dilihat pada Tabel 2.

\section{Kadar air}

Hasil sidik ragam menunjukkan bahwa perbandingan mocaf dengan tepung kacang hijau berpengaruh nyata $(\mathrm{P}<0,05)$ terhadap kadar air tuile. Tabel 2 menunjukkan nilai rata-rata kadar air terendah tuile didapatkan pada perlakuan P6 $(0,47 \%)$ serta tidak berbeda dengan perlakuan P5 dan P4, sedangkan kadar air tertinggi tuile didapatkan pada perlakuan P1 (2,06\%) serta tidak berbeda dengan perlakuan P2 dan P3. Hal ini menunjukkan bahwa semakin banyak penambahan tepung kacang hijau, maka kadar air tuile semakin menurun. Penurunan nilai kadar air tersebut sesuai dengan hasil analisis bahan baku mocaf dan tepung kacang hijau pada Tabel 1, didapatkan kadar air mocaf sebesar $11,79 \%$ sedangkan kadar air tepung kacang hijau sebesar 8,05\%.

Tuile merupakan produk kue kering sehingga dibutuhkan kadar air yang rendah untuk menghasilkan tekstur yang renyah. Menurut Wihenti et al. (2017) menyatakan bahwa semakin rendah kadar air pada kue kering maka semakin renyah tekstur yang dihasilkan. Rendahnya kadar air tuile disebabkan oleh suhu oven ketika proses pemanggangan.

Tabel 1. Nilai rata-rata kadar air, kadar abu, kadar protein, kadar lemak, kadar karbohidrat dan kadar serat kasar dari mocaf dan tepung kacang hijau.

\begin{tabular}{lccc}
\hline & Komponen & Mocaf & Tepung Kacang hijau \\
\hline Air (\%) & 11,79 & 8,05 \\
Abu (\%) & 1,07 & 3,07 \\
Protein (\%) & 1,88 & 23,41 \\
Lemak (\%) & 1,92 & 2,49 \\
Karbohidrat (\%) & 83,32 & 62,95 \\
Serat Kasar (\%) & 4,51 & 9,45 \\
\hline
\end{tabular}

Tabel 2. Nilai rata-rata kadar air, kadar abu, kadar protein, kadar lemak, kadar serat kasar dan kadar karbohidrat dari tuile.

\begin{tabular}{lcccccc}
\hline Perlakuan & $\begin{array}{c}\text { Kadar } \\
\text { Air }(\%)\end{array}$ & $\begin{array}{c}\text { Kadar Abu } \\
(\%)\end{array}$ & $\begin{array}{c}\text { Kadar Protein } \\
(\%)\end{array}$ & $\begin{array}{c}\text { Kadar Lemak } \\
(\%)\end{array}$ & $\begin{array}{c}\text { Kadar } \\
\text { Karbohidrat } \\
(\%)\end{array}$ & $\begin{array}{c}\text { Kadar Serat } \\
\text { Kasar }(\%)\end{array}$ \\
\hline P1(100:0) & $2,06 \pm 1,09 \mathrm{a}$ & $1,06 \pm 0,34 \mathrm{c}$ & $5,15 \pm 0,37 \mathrm{e}$ & $14,61 \pm 1,06 \mathrm{a}$ & $77,09 \pm 1,27 \mathrm{a}$ & $4,32 \pm 0,44 \mathrm{e}$ \\
P2(90:10) & $1,50 \pm 0,61 \mathrm{ab}$ & $1,21 \pm 0,36 \mathrm{c}$ & $6,44 \pm 0,14 \mathrm{~d}$ & $15,08 \pm 0,72 \mathrm{a}$ & $75,75 \pm 0,55 \mathrm{ab}$ & $4,91 \pm 0,33 \mathrm{~d}$ \\
P3(80:20) & $1,33 \pm 0,53 \mathrm{ab}$ & $1,41 \pm 0,27 \mathrm{~b}$ & $7,84 \pm 0,36 \mathrm{c}$ & $15,15 \pm 0,30 \mathrm{a}$ & $74,25 \pm 0,94 \mathrm{bc}$ & $5,30 \pm 0,49 \mathrm{c}$ \\
P4(70:30) & $1,16 \pm 0,53 \mathrm{bc}$ & $1,46 \pm 0,24 \mathrm{~b}$ & $8,54 \pm 0,39 \mathrm{c}$ & $15,49 \pm 0,27 \mathrm{a}$ & $73,33 \pm 0,89 \mathrm{~cd}$ & $5,36 \pm 0,46 \mathrm{c}$ \\
P5(60:40) & $0,94 \pm 0,34 \mathrm{bc}$ & $1,63 \pm 0,23 \mathrm{a}$ & $10,14 \pm 0,57 \mathrm{~b}$ & $15,54 \pm 0,97 \mathrm{a}$ & $71,72 \pm 1,22 \mathrm{de}$ & $5,87 \pm 0,48 \mathrm{~b}$ \\
P6(50:50) & $0,47 \pm 0,39 \mathrm{c}$ & $1,75 \pm 0,24 \mathrm{a}$ & $11,57 \pm 0,63 \mathrm{a}$ & $15,72 \pm 1,05 \mathrm{a}$ & $70,47 \pm 1,17 \mathrm{e}$ & $6,35 \pm 0,31 \mathrm{a}$ \\
\hline
\end{tabular}

Keterangan: Nilai rata-rata yang diikuti oleh huruf yang berbeda pada kolom yang sama menunjukkan berbeda nyata $(\mathrm{P}<0,05)$.

Nilai rata-rata \pm standar deviasi $(n=3)$ 
Ramadani et al. (2017) menyatakan bahwa semakin tinggi suhu udara pengering, makin besar energi panas yang dibawa udara sehingga makin banyak jumlah massa cairan yang diuapkan dari permukaan bahan yang dikeringkan.

Mengacu pada syarat mutu biskuit (SNI 01-2973-2011), kadar air pada biskuit adalah maksimal 5\% sedangkan kadar air tertinggi tuile pada penelitian ini adalah 2,06\% sehingga kadar air pada tuile sudah memenuhi syarat mutu biskuit (SNI 01-2973-2011).

\section{Kadar Abu}

Hasil sidik ragam menunjukkan bahwa perbandingan mocaf dengan tepung kacang hijau berpengaruh sangat nyata $(\mathrm{P}<0,01)$ terhadap kadar abu tuile. Tabel 2 menunjukkan nilai rata-rata kadar abu tuile terendah diperoleh pada perlakuan P1 $(1,06 \%)$ dan tidak berbeda dengan perlakuan P2, sedangkan kadar abu tuile tertinggi diperoleh pada perlakuan P6 (1,75\%) dan tidak berbeda dengan perlakuan P5. Hal ini menunjukkan bahwa semakin tinggi penambahan tepung kacang hijau, maka kadar abu tuile semakin meningkat. Peningkatan nilai kadar abu tersebut sesuai dengan hasil analisis bahan baku mocaf dan tepung kacang hijau pada Tabel 1, didapatkan kadar abu mocaf sebesar $1,07 \%$ sedangkan kadar abu tepung kacang hijau sebesar 3,07\%.

Menurut Muchtadi (2010) dalam Azizah et al., (2014) menyatakan bahwa kacang hijau merupakan sumber mineral kalsium (223mg per $100 \mathrm{~g}$ bahan), fosfor (319mg per 100g bahan), dan besi (7,5mg per $100 \mathrm{~g}$ bahan). Mineral memiliki peran penting dalam tubuh karena berfungsi sebagai zat pembangun dan pengatur metabolisme di dalam tubuh.

\section{Kadar Protein}

Hasil sidik ragam menunjukkan bahwa perbandingan mocaf dengan tepung kacang hijau berpengaruh sangat nyata $(\mathrm{P}<0,01)$ terhadap kadar protein tuile. Tabel 2 menunjukkan nilai rata-rata kadar protein tuile terendah didapatkan pada perlakuan P1 $(5,15 \%)$ sedangkan kadar protein tuile tertinggi didapatkan pada perlakuan P6 $(11,57 \%)$. Hal ini menunjukkan bahwa semakin tinggi penambahan tepung kacang hijau, maka kadar protein tuile semakin meningkat. Peningkatan nilai kadar protein tersebut sesuai dengan hasil analisis bahan baku mocaf dan tepung kacang hijau pada Tabel 1, didapatkan kadar protein mocaf sebesar $1,88 \%$ sedangkan kadar protein tepung kacang hijau sebesar 23,41\%.

Kandungan protein tuile pada penelitian ini paling banyak berasal dari tepung kacang hijau. Kacang hijau kaya akan asam amino, terutama asam amino esensial yang hanya dapat diperoleh melalui asupan makanan, yaitu isoleusin $(6,95 \%)$, leusin $(12,9 \%)$, lisin $(7,94)$ metionin $(0,84 \%)$, fenilalanin $(7,07 \%)$, treonin $(4,50 \%)$, dan valin $(8,23 \%)$ (Adrianto dan Indranto, 2004). Menurut Diana (2009) menyatakan bahwa protein di dalam tubuh berfungsi sebagai sumber energi utama selain karbohidrat dan lemak, sebagai zat pengatur proses metabolisme dalam bentuk enzim dan hormon, sebagai mekanisme pertahanan tubuh melawan berbagai mikorba dan zat toksik lain yang datang dari luar, serta memelihara sel dan jaringan tubuh.

Mengacu pada syarat mutu biskuit (SNI 01-2973-2011), kadar protein pada biskuit adalah minimal 5\% sedangkan kadar protein terendah tuile pada penelitian ini adalah $5,15 \%$ sehingga kadar protein pada tuile sudah memenuhi syarat mutu biskuit (SNI 012973-2011).

\section{Kadar Lemak}

Hasil sidik ragam menunjukkan bahwa perbandingan mocaf dengan tepung kacang hijau berpengaruh tidak nyata $(\mathrm{P}>0,05)$ terhadap kadar lemak tuile. Tabel 2 menunjukkan nilai rata-rata kadar lemak tuile berkisar pada angka $14,61 \%-15,72 \%$. 


\section{Kadar Karbohidrat}

Hasil sidik ragam menunjukkan bahwa perbandingan mocaf dengan tepung kacang hijau berpengaruh sangat nyata $(\mathrm{P}<0,01)$ terhadap kadar karbohidrat tuile. Tabel 2 menunjukkan nilai rata-rata kadar karbohidrat tuile terendah diperoleh pada perlakuan P6 $(64,12 \%)$ dan tidak berbeda dengan perlakuan P5 sedangkan kadar karbohidrat tuile tertinggi diperoleh dari perlakuan P1 $(72,7 \%)$ dan tidak berbeda dengan perlakuan P2. Hal ini menunjukkan bahwa semakin tinggi penambahan tepung kacang hijau, maka kadar karbohidrat tuile semakin rendah. Peningkatan nilai kadar karbohidrat tersebut sesuai dengan hasil analisis bahan baku mocaf dan tepung kacang hijau pada Tabel 1 didapatkan kadar karbohidrat mocaf sebesar $83,32 \%$ sedangkan kadar karbohidrat tepung kacang hijau sebesar $62,95 \%$.

\section{Kadar Serat Kasar}

Hasil sidik ragam menunjukkan bahwa perbandingan mocaf dengan tepung kacang hijau berpengaruh sangat nyata $(\mathrm{P}<0,01)$ terhadap kadar serat kasar tuile. Tabel 2 menunjukkan nilai rata-rata kadar serat kasar tuile terendah diperoleh pada perlakuan P1 $(4,32 \%)$, sedangkan kadar serat kasar tuile tertinggi diperoleh dari perlakuan P6 $(6,35 \%)$. Hal ini menunjukkan bahwa semakin tinggi penambahan tepung kacang hijau, maka kadar serat kasar tuile semakin meningkat. Peningkatan nilai kadar serat kasar tersebut sesuai dengan hasil analisis bahan baku mocaf dan tepung kacang hijau pada Tabel 1 didapatkan kadar serat kasar mocaf sebesar 4,51\% sedangkan kadar serat kasar tepung kacang hijau sebesar 9,45\%.

Tabel 3. Nilai rata-rata uji hedonik warna, tekstur, aroma, rasa dan penerimaan keseluruhan tuile

\begin{tabular}{cccccc}
\hline Perlakuan & Warna & Aroma & Tekstur & Rasa & $\begin{array}{c}\text { Penerimaan } \\
\text { Keseluruhan }\end{array}$ \\
\hline (P1)100:0 & $6,00 \mathrm{a}$ & $5,06 \mathrm{a}$ & $4,66 \mathrm{c}$ & $5,20 \mathrm{bc}$ & $5,13 \mathrm{~b}$ \\
(P2)90:10 & $5,60 \mathrm{ab}$ & $5,20 \mathrm{a}$ & $4,93 \mathrm{c}$ & $5,60 \mathrm{ab}$ & $5,00 \mathrm{~b}$ \\
(P3)80:20 & $5,33 \mathrm{bc}$ & $5,26 \mathrm{a}$ & $5,53 \mathrm{~b}$ & $5,80 \mathrm{a}$ & $5,73 \mathrm{a}$ \\
(P4)70:30 & $4,93 \mathrm{c}$ & $5,33 \mathrm{a}$ & $6,20 \mathrm{a}$ & $5,40 \mathrm{ab}$ & $5,53 \mathrm{a}$ \\
(P5)60:40 & $4,40 \mathrm{~d}$ & $5,40 \mathrm{a}$ & $4,60 \mathrm{c}$ & $4,93 \mathrm{~cd}$ & $4,53 \mathrm{c}$ \\
(P6)50:50 & $4,20 \mathrm{~d}$ & $5,53 \mathrm{a}$ & $4,53 \mathrm{c}$ & $4,60 \mathrm{~d}$ & $4,40 \mathrm{c}$ \\
\hline
\end{tabular}

Keterangan: Nilai rata-rata yang diikuti oleh huruf yang berbeda pada kolom yang sama menunjukkan berbeda nyata $(\mathrm{P}<0,05)$.

Kriteria hedonik: 1 (sangat tidak suka), 2 (tidak suka), 3 (agak tidak suka), 4 (biasa), 5 (agak suka), 6 (suka), dan 7 (sangat suka)

Tabel 4. Nilai rata-rata uji skoring tekstur tuile

\begin{tabular}{|c|c|}
\hline \multirow{2}{*}{ Perlakuan } & Nilai Rata-Rata Uji Skoring \\
\hline & Tekstur \\
\hline (P1)100:0 & $4,60 \mathrm{~d}$ \\
\hline (P2)90:10 & $5,13 \mathrm{c}$ \\
\hline (P3) $80: 20$ & $5,46 b c$ \\
\hline (P4)70:30 & $5,53 \mathrm{bc}$ \\
\hline (P5)60:40 & $5,73 \mathrm{ab}$ \\
\hline (P6) $50: 50$ & $6,13 \mathrm{a}$ \\
\hline
\end{tabular}

Keterangan: Nilai rata-rata yang diikuti oleh huruf yang berbeda pada kolom yang sama menunjukkan berbeda nyata $(\mathrm{P}<0,05)$.

Kriteria Skoring: 1 (sangat keras), 2 (keras), 3 (agak keras), 4 (biasa), 5 (agak renyah), 6 (renyah), dan 7 (sangat renyah). 
Komponen serat kasar pada kacang hijau yaitu selulosa, hemiselulosa dan lignin (Mustakim, 2014). Menurut Saifullah et al. (2009) menyatakan bahwa serat kasar memberikan dampak positif bagi kesehatan untuk mengurangi resiko penyakit degeneratif diantaranya adalah menurunkan respon insulin dan indeks glikemik bahan pangan, menurunkan kadar kolesterol yang berlebihan, dan menurunkan resiko penyakit kanker kolon.

\section{Evaluasi Sensoris}

Evaluasi sifat sensoris tuile dilakukan dengan uji hedonik terhadap warna, tekstur, aroma, rasa dan penerimaan keseluruhan serta uji skoring terhadap tekstur tuile. Nilai rata-rata uji hedonik terhadap warna, tekstur, aroma, rasa dan penerimaan keseluruhan tuile dapat dilihat pada Tabel 4 serta nilai rata-rata uji skoring terhadap tekstur dapat dilihat pada pada Tabel 5.

\section{Warna}

Hasil sidik ragam menunjukkan bahwa perbandingan mocaf dengan tepung kacang hijau berpengaruh sangat nyata $(\mathrm{P}<0,01)$ terhadap uji hedonik warna dari tuile. Tabel 3 menunjukkan bahwa nilai rata-rata tertinggi diperoleh pada tuile perlakuan P1 dengan kriteria suka serta tidak berbeda dengan P2, sedangkan nilai rata-rata terendah diperoleh pada tuile perlakuan P6 dengan kriteria biasa serta tidak berbeda dengan P5.

Panelis menyukai warna tuile perlakuan P1 dan P2 yang memiliki komposisi mocaf lebih tinggi dibandingkan dengan perlakuan lainnya. Mocaf mengandung karbohidrat sebesar 87,3\% (Damayanti et al., 2014). Produk pangan yang mengandung karbohidrat dan protein ketika dipanaskan akan menimbulkan reaksi maillard. Winarno (2002) menyatakan bahwa reaksi maillard merupakan reaksi pencoklatan non enzimatis antara gula preduksi dan gugus amin bebas dari asam amino atau protein, sehingga mengakibatkan warna pada bahan pangan menjadi coklat. Pemanasan menyebabkan terjadinya rekasi maillard yang membentuk melanoit yaitu zat warna kuning kecoklatan pada tuile. Hal tersebut yang menyebabkan warna tuile pada perlakuan P1 dan P2 lebih disukai dibadingkan dengan perlakuan lainya. Adapun seiring penambahan tepung kacang hijau yang semakin meningkat menghasilkan warna tuile yang semakin gelap dan kurang disukai oleh panelis. Hal ini disebabkan karena adanya kandungan pigmen warna hijau pada tepung kacang hijau, sehingga mempengaruhi warna coklat tuile yang dihasilkan. Winarno (2004) menyatakan bahwa suatu bahan pangan meskipun dinilai enak dan teksturnya sangat baik, tetapi memiliki warna yang tidak menarik atau memberi kesan telah menyimpang dari warna yang seharusnya maka bahan tersebut tidak akan dikonsumsi.

\section{Aroma}

Hasil sidik ragam menunjukkan bahwa perbandingan mocaf dengan tepung kacang hijau berpengaruh tidak nyata $(\mathrm{P}>0,05)$ terhadap nilai rata-rata uji hedonik aroma dari tuile. Tabel 3 menunjukkan bahwa nilai ratarata dari uji hedonik aroma tuile adalah suka.

\section{Tekstur}

Hasil sidik ragam menunjukkan bahwa perbandingan mocaf dengan tepung kacang hijau berpengaruh sangat nyata $(\mathrm{P}<0,01)$ terhadap uji hedonik dan berpengaruh sangat nyata $(\mathrm{P}<0,01)$ terhadap uji skor tekstur dari tuile. Tabel 3 menunjukkan nilai rata-rata uji hedonik tekstur tuile tertinggi diperoleh pada perlakuan P4 dengan kriteria suka sedangkan nilai rata-rata terendah diperoleh pada tuile dengan pada perlakuan P6 dengan kriteria agak suka serta tidak berbeda dengan perlakuan P1, P2 dan P5.

Tabel 4 menunjukkan bahwa nilai ratarata dari uji skor tekstur tuile tertinggi diperoleh pada P6 dengan kriteria tekstur renyah serta tidak berbeda dengan P5, sedangkan nilai rata-rata terendah diperoleh 
pada perlakuan P1 dengan kriteria tekstur agak renyah.

Panelis menyukai tekstur pada tuile perlakuan P4 karena tuile menghasilkan tekstur yang renyah. Penambahan tepung kacang hijau yang semakin meningkat menghasilkan tekstur tuile yang semakin renyah. Hal tersebut juga seiring dengan menurunnya kadar air pada tuile $(2,06 \%$ $0,47 \%)$. Semakin rendah kadar air produk maka semakin renyah tuile yang dihasilkan. Menurut Nurdjanah et al. (2011) menyatakan bahwa kadar air pada kue kering merupakan karakteristik yang akan mempengaruhi penerimaan konsumen terutama pada tekstur atau tingkat kerenyahan kue kering. Wihenti et al. (2017) menambahkan bahwa tekstur yang renyah pada kue kering dikarenakan kadar air yang rendah yang terkandung pada produk pangan tersebut. Adapun ketebalan tuile yang tipis berpengaruh terhadap tekstur, sehingga menghasilkan tekstur tuile yang renyah. Menurut Mahmudah (2013) tebal kue kering juga berperan pada kekerasan kue kering tersebut, semakin tebal kue kering, semakin besar pula gaya atau daya menghancurkan tekstur kue kering pada saat dikonsumsi.

\section{Rasa}

Hasil sidik ragam menunjukkan bahwa perbandingan mocaf dengan tepung kacang hijau berpengaruh sangat nyata $(\mathrm{P}<0,01)$ terhadap uji hedonik rasa tuile. Nilai rata-rata dari uji hedonik rasa tuile pada Tabel 3 menunjukkan bahwa nilai rata-rata tertinggi diperoleh pada tuile perlakuan P3 dengan kriteria suka serta tidak berbeda dengan P2 dan $\mathrm{P} 4$ sedangkan nilai rata-rata terendah diperoleh pada tuile perlakuan P6 dengan kriteria agak suka serta tidak berbeda dengan P5.

Panelis menyukai rasa tuile perlakuan P3 yang memiliki komposisi mocaf lebih tinggi dibandingkan dengan perlakuan lainnya. Menurut Damayanti et al. (2014) menyatakan bahwa mocaf memiliki kandungan karbohidrat kompleks yang tinggi (87,3\%) sehingga akan menghasilkan rasa yang lebih manis ketika diolah. Selain hal tersebut karena adanya penambahan tepung kacang hijau, tuile yang dihasilkan memiliki rasa yang khas dan menarik sehingga disukai oleh panelis. Menurut Sari (2016) komposisi bahan pangan merupakan salah satu faktor penentu cita rasa makanan, makanan yang memiliki rasa yang enak dan menarik akan disukai oleh panelis.

\section{Penerimaan Keseluruhan}

Hasil sidik ragam menunjukkan bahwa perbandingan mocaf dengan tepung kacang hijau berpengaruh sangat nyata $(\mathrm{P}<0,01)$ terhadap penerimaan keseluruhan tuile. Tabel 3 menunjukkan bahwa nilai rata-rata tertinggi diperoleh pada tuile perlakuan $\mathrm{P} 3$ dengan kriteria suka serta tidak berbeda dengan P4, sedangkan nilai rata-rata terendah diperoleh pada tuile perlakuan P6 dengan kriteria biasa serta tidak berbeda dengan P5. Penerimaan keseluruhan tuile dipengaruhi oleh beberapa faktor seperti warna, aroma, tekstur dan rasa. Nilai rata-rata kesukaan keseluruhan tersebut menunjukkan bahwa tuile yang terbuat dari mocaf dan tepung kacang hijau dapat diterima dengan cukup baik oleh panelis.

\section{KESIMPULAN DAN SARAN}

\section{Simpulan}

Berdasarkan hasil penelitian yang telah dilakukan dapat diambil kesimpulan sebagai berikut:

1. Perbandingan mocaf dengan tepung kacang hijau berpengaruh terhadap kadar air, kadar abu, kadar protein, kadar karbohidrat, kadar serat kasar, warna, rasa (uji hedonik), tektur (uji hedonik dan uji skoring) dan penerimaan keseluruhan (uji hedonik) serta berpengaruh tidak nyata terhadap kadar lemak dan aroma (uji hedonik).

2. Perbandingan $70 \%$ mocaf : $30 \%$ tepung kacang hijau merupakan karakteristik 
terbaik dengan kadar air 1,16\%, kadar abu $1,46 \%$, kadar protein $8,54 \%$, kadar lemak $15,49 \%$, kadar karbohidrat 73,33\%, kadar serat kasar 5,36\%, warna agak suka, aroma agak suka, tekstur renyah dan suka, rasa agak suka, serta penerimaan keseluruhan agak suka.

\section{Saran}

Berdasarkan penelitian diatas disarankan untuk melakukan penelitian lebih lanjut mengenai umur simpan tuile dengan perbandingan $70 \%$ mocaf : $30 \%$ tepung kacang hijau sehingga menghasilkan tuile dengan karakteristik terbaik.

\section{DAFTAR PUSTAKA}

Andrianto, T.T. dan N. Indranto. 2004. Budi Daya dan Analisis Usaha Tani Kedelai Kacang Hijau Kacang Panjang. Absolut. Yogyakarta.

Anonimus. 2010. The Pastry Sampler. http://www.pastrysampler.com/Questio ns_and_Answers/tuile.htm. Diakses pada tanggal 30 Januari 2018.

Azizah, Y.N., D. Rachmawanti, dan D. Rahardian. 2014. Formulasi dan kajian karakteristik nasi jagung (Zea mays L) instan yang disubtitusi tepung kacang ijau (Phaseolus radiates). Jurnal Teknologi Pangan. 3(1): 84-95.

Biró., Marcel and Shannon Kring. 2005. European-Inspired Cuisine. Gibbs Smith. London.

Diana, F. M. 2009. Fungsi dan metabolisme protein dalam tubuh manusia. Jurnal Kesehatan Masyarakat. Studi Literatur. 4 (1): 47-53.

Gomez, K.A. dan A.A. Gomez. 1995. Prosedur Statistik untuk Penelitian Pertanian. (Terjemahan). E. Syamsudin dan J. S. Baharsjah. UI Press. Jakarta. p. 698.
Mahmudah, S. 2013. Pengaruh substitusi tepung tulang ikan lele (Clarias batrchus) terhadap kadar kalsium, kekerasan dan daya terima biskuit. Jurnal Publikasi. Fakultas Ilmu Kesehatan. Universitas Muhamadiyah Surakarta.

Mustakim, M. 2014. Budidaya Kacang Hijau Secara Intensif. Pustaka Baru Press. Yogyakarta.

Nurdjanah, S., N. Musita, dan D. Indrianti. 2011. Karakteristik biskuit coklat dari campuran tepung pisang batu (Musa balbisiana Colla) dan tepung terigu pada berbagai tingkat substitusi. Jurnal Teknologi dan Industri Hasil Pertanian. 1(16): 51-62.

Nisa, R.U. 2016. Perbandingan Tepung Sukun (Artocarpus communis) Dengan Tepung Kacang Hijau (Vigna radiata L) Dan Suhu Pemanggangan Terhadap Karakteristik Cookies. Skripsi. Tidak dipublikasikan. Jurusan Teknologi Pangan. Fakultas Teknik. Universitas Pasundan. Bandung.

Nusa, M.I., B. Suarti, dan Alfiah. 2012. Pembuatan tepung mocaf (modified cassava flour) melalui penambahan stater dan lama fermentasi. Agrium. 17 (3): 210-218.

Ramadani, R.W., H.M. Yahya, dan J. Palla. 2017. Perubahan kadar air dan kadar pati ubi kayu (Manihot utilissima) selama pengeringan menggunakan room dryer. Jurnal Pendidikan Teknologi Pertanian. 3 : 102-111.

Ratnasari, D. dan Yuanita. 2015. Pengaruh tepung kacang hijau, tepung labu kuning, margarin terhadap fisikokimia dan organoleptik biskuit. Jurnal Pangan. 3(4) : 1652-1661.

Saifullah, R., F.M.A. Abbas, S.Y. Yeoh dan M.E. Azhar. 2009. Utilization of green 
banana flour as a functional ingredient in yellow noodle. International Food Research Journal 16 : 373-379.

Sari, S.M. 2016. Perbandingan Tepung Sorgum, Tepung Sukun, dengan Kacang Tanah dan Jenis Gula terhadap Karakteristik Snack Bar. Skripsi. Tidak dipublikasikan. Program Studi Teknologi Pangan Universitas Pasundan. Bandung.

Sidabutar, W.D.R., R.J. Nainggolan dan Ridwansyah. 2013. Kajian Penambahan Tepung Talasan Dan Tepung Kacang Hijau Terhadap Mutu Cookies. Skripsi. Tidak dipublikasikan. Sarjana Program Studi Ilmu dan Teknologi Pangan. Fakultas Pertanian. USU. Medan.

Soekarto, S.T. 1985. Penilaian Organoleptik Untuk Industri Pangan dan Pertanian. Bharata Karya Aksara. Jakarta.

Subagio, A. 2007a. Industrialisasi Modified Cassava Flour (Mocaf) Sebagai Bahan Baku Industri Pangan Untuk Menunjang Diversifikasi Pangan Pokok Nasional. Majalah Trubus Edisi 2009. Jakarta.

Subagio, A. 2008. Modified cassava flour (mocaf) sebuah masa depan ketahanan pangan nasional berbasis potensi lokal. Jurnal Pangan. 17 (1): 92-104.

Sudarmadji., S.B. Haryono dan Suhardi. 1997. Prosedur Analisa Untuk Bahan Makanan dan Pertanian. Liberty. Yogyakarta.

Tanjung, Y.L. dan J. Kusnadi. 2015. Biskuit bebas gluten dan bebas kasein bagi penderita autis. Jurnal Pangan dan Agroindustri. 3(1) : 11-22.

Wihenti, A.I., B.E. Setiani, dan A. Hintono. 2017. Analisis kadar air, tebal, berat dan tekstur biskuit cokelat akibat perbedaan transfer panas. Jurnal Aplikasi Teknologi Pangan. 6 (2): 69-74.
Winarno, F.G. 2002. Kimia Pangan dan Gizi. Gramedia. Jakarta.

Winarno, F.G. 2004. Hasil-hasil Simposium Penganekaragaman Pangan. Prakarsa Swasta dan Pemda. Jakarta. 